
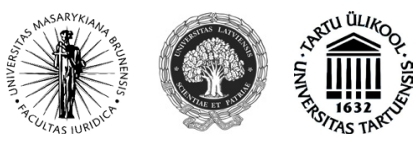

ISSN 1392-6195 (print) ISSN 2029-2058 (online) JURISPRUDENCIJA JURISPRUDENCE 2014, 21(1), p. 204-222.

\title{
LEGAL CERTAINTY AS A BASIC PRINCIPLE OF THE LAND LAW OF UKRAINE
}

\author{
Bronislav Totskyi \\ National Academy of Sciences of Ukraine \\ Koretsky Institute of State and Law \\ Triokhsviatytelska str. 4, Kyiv, Ukraine, 01601 \\ Tel.: +380636178900 \\ E-mail: Bronislav.totskyi@gmail.com \\ Received on 17 November 2013, accepted on 13 March 2014 \\ doi:10.13165/JUR-14-21-1-10
}

\section{Introduction}

Structural changes in Ukrainian legislation, including land law, are leading to the legal system modernization on European standards. Particular attention is paid to the rights limitation standards through the use of the principle of proportionality. One of the structural parts of the proportionality principle is the legal certainty, which places a number of requirements for legislative and law enforcement.

Importance of the legal certainty in the legal system has been pointed out by a pre-revolutionary law scholar Josef Pokrovsky in the 19th century: "one of the first and most essential requirements that apply to the individual rights developments is a legal certainty. If everyone must obey the law and adapt behavior to certain requirements, the first condition of orderly social life is the certainty of these requirements".

1 Pokrovskij, I. A. Osnovnyje problemy grazhdanskogo prava. The Main Problems of Civil Law]. Moscow, 1998, p. 89.

Jurisprudencija/Jurisprudence

(C) Mykolo Romerio universitetas, 2014

(C) Mykolas Romeris University, 2014
ISSN 1392-6195 (print), ISSN 2029-2058 (online) http://www.mruni.eu/lt/mokslo_darbai/jurisprudencija/ http://www.mruni.eu/en/mokslo_darbai/jurisprudencija/ 
The presence of a formal (legal) certainty is a multiple meaningful value. Law establishes certain formal requirements for legislative and enforcement activity that is governed by special rules. It regulates not only state activities, but also the form of enforcement acts, term actions, rights and obligations, etc. Ignorance of this legal principle could lead to the tyranny and injustice in the state.

The purpose of this article is to explore historical and theoretical origins of the principle of legal certainty. The ECHR practice in the legal certainty application as a main source of its practical usage is analyzed, too. The final part of the article is aimed to show the practical usage of the principle of legal certainty in Ukrainian land sphere.

The principle of legal certainty has been explored by many scholars from all parts of the world. Alexy, Barak, Hayek, Held, Radbruch, Rawls, Tamanaha, etc., were researching different aspects of legal certainty. At the same time, there has been no complex research, where theoretical analysis of legal certainty was connected with its practical examination by the Constitutional Court of Ukraine in a concrete sphere, e.g., land sphere.

The author used different research methods in this paper to reach the goals noted before. In the first chapter titled "Historical origins of the legal certainty", the author is exploiting historical method of research to find the earliest legal certainty application in Ancient Greece and Rome. The goal of this part is to show ancient roots of the principle of legal certainty. The second part of the article called "Theoretical basis of legal certainty" is based on the theoretical methodology to find out academic and abstract foundation of the legal certainty principle. In the third and fourth parts of the article named "Legal certainty in the ECHR practice" and "Practical application of legal certainty in land relationships in Ukraine", comparative methods and practical analysis to investigate practical application of legal certainty in general practice of the ECHR are used to compare with concrete Ukrainian legislation and the Constitutional Court of Ukraine practice in a concrete sphere - land law of Ukraine.

\section{Historical origins of legal certainty}

Legal certainty takes origins in the Ancient Greek and Roman law. Tyrant's decrees could at any time change Greek laws, which, adopted at the public meeting laws, were certain and democratic. All the laws were totally clear and understandable in the second half of the 5th-4th centuries BC. They had a casuistic character, so they could be replaced by other laws that would have a broader scope and also install another regulation ${ }^{2}$. 
The modern concept of legal certainty that is applied in Article 22 of the Constitution of Ukraine ${ }^{3}$ was also used in Ancient Greece: "Constitutional rights and freedoms are guaranteed and cannot be canceled. New laws adoption or existing laws amendments shall not be diminished content and scope of existing rights and freedoms".

Every citizen could file a lawsuit against the law author that is approved by the national assembly if the law contains serious flaws and contraries to the older laws in force or obvious rights limits of Athenian citizens. The author of the law could be fined or punished by other means till capital punishment. Such law was cancelled by the national assembly ${ }^{4}$.

The Athenian democracy recognized the category of definiteness only as the exact wording of the legal text during the 5th-4th centuries BC. Such determination is a short termed and unstable because it cannot provide stability of the application of the same standards and norms ${ }^{5}$.

The concept of legal certainty was implemented more in the judiciary than legislature in Ancient Rome. The first definition of legal certainty - res iudicata, which literally means a "decided case", was made by the judiciary ${ }^{6}$.

Prof. Dozhdyev cites the following examples that illustrate the prejudicial character of a judgment. The claimant did not have to re-prove the ownership of the land and the denial of the defendant was not taken into consideration if property right was the subject of a judgment. The decision was important to all third parties: sued for easement need not be the same person as the party of the previous process ${ }^{7}$.

The judge set the certainty and stability of judicial practice above justice in his decision that it could not be challenged or has been upheld by a higher court in postclassical period ${ }^{8}$. Legal certainty originated from res iudicata, but has not been yet understood as a separate independent principle of law by the Roman lawyers.

The principle of legal certainty was developed in different countries in different ways. Legal certainty requirements implementation can be found in the Magna Carta (1215), the Declaration of the Rights of Man (1989) and even in the Covenant and the Constitution of the rights and liberties of the Zaporozhian known as Orlyk Constitution (1710). However, the theoretical and practical development of legal

3 Konstytucija Ukrainy [Constitution of Ukraine]. Vidomosti Verhovnoi Rady Ukrainy. 1996, № 30.

4 Bruno, L. Freedom and the Law. Los Angeles: Nash Publishing, 2008, p. 98.

5 Matvejeva, Ju. I. Pryncyp pravovoi vyznachenosti: istorychni pidhody ta suchasne rozuminnja [The Principle of Legal Certainty: Historical Approaches and Current Understanding]. Naukovi zapysky NaUKMA. 2011, 116 (Jurydychni nauky): 29-31.

6 The Digest of Justinian. Vol. 2. Philadelphia: University of Philadelphia Press, p. 27-28.

7 Dozhdev, D. V. Rymskoe chastnoe pravo [Roman Private Law]. Moscow, 2008, p. 249.

8 Rehtyna, Y. V. Pravovaja opredelennost' (res judicata) v ystoryy prava Drevnego Ryma [Legal Certainty (Res Judicata) in Legal History of Ancient Rome]. История государства и права. 2011, 22: 43-47. 
certainty was made in the 20th-21st centuries AD. The European Court of Human Rights (hereinafter - the ECHR) played a great role in the legal certainty theory development.

\section{Theoretical basis of legal certainty}

Legal certainty in the theoretical aspect is a set of requirements for the organization and functioning of the legal system in order to ensure a stable personal legal status by improving the process of law-making and enforcement. Legal certainty aims at adaptation of the individual behavior to the legal validity standards, protection from the State interference and individual confidence in the legal status reliability ${ }^{9}$.

Legal certainty raises a number of legislative and enforcement requirements. The basic requirements of legal certainty can be divided into groups of formal and structural requirements.

The formal requirements include the criteria regarding external form of legislation.

Specific restrictions on rights must be provided for a specific legal act. This criterion is subject not only to the so-called "written law", but also to the unwritten law, including common law ${ }^{10}$.

The presence of social legitimization is the main aspect in determining whether a particular restriction was set by legal acts. Even delegation of rulemaking function to the self-governing body or organization does not necessarily contradict legal certainty until this body formulates and promulgates regulations prior to use. Hayek noted that there is a consumer delegation problem. The government uses coercion in the absence of rules that are not established by organizations, to which establishing powers of these rules was delegated ${ }^{11}$. Hayek believes that serious problems cannot arise from the fact that the Parliament or any other body, to which power was publicly delegated, adopts rules. General rules that provide an opportunity to anticipate and plan actions according to the possible consequences must be drafted properly and be well-known.

It is written that the specific legal act must take place, but it does not mean that that concrete situation must be described in it. "No publication that may affect national security is allowed" principle is not directly written in many countries. However, everybody understands this rule. This principle could be derived from the

9 Kozjubra M. I. Pryncyp verhovenstva prava ta pravovoi' derzhavy: jednist osnovnyh vymog [Rule of Law and Rechtsstaat: The Unity of the Basic Requirements]. Naukovi zapysky NaUKMA. 2007, 64 (Jurydychni nauky): 3-9.

10 Sunday Times $v$. The United Kingdom, No. 6538/74, \$47, 2 EHRR 245.

11 Hayek, F. Law, Legislation and Liberty. Vol. 2. London and Chicago: University of Chicago Press, 1976, p. 321. 
Rule of Law and the Constitution. Such interpretation is performed in accordance with the standard rules of statutory interpretation ${ }^{12}$.

Each restrictive act must be public (non obligat lex nisi promulgata). State must take necessary steps to bring laws to the public notice and ensure their availability if it requires the knowledge of its citizens and law enforcement. "The law must be adequately accessible: the citizen must be able to have an indication that is adequate in the circumstances of the legal rules applicable to a given case"13.

"Secret law" or regulation that has a general character, but is promulgated behind the closed doors, could not be accessible so it would be unconstitutional. Of course, some rules could not be published because of the availability of security mark. But this regulation could not be general and should have a narrow scope of use.

Each state has its own procedure for official promulgation of regulations. The main acts that regulate official promulgation in Ukraine are the following ones: the President's Decree "On the official publication of regulations and their entry into force” (10.06.1997, № 503/97) ${ }^{14}$, the President’s Decree “On publication of legislative acts of Ukraine in the newsletter "Official Gazette of Ukraine"” (13.12.1996) ${ }^{15}$. These acts establish the order of the official announcement of major regulations. Most regulations are placed on authorities of Internet portals, except those that include security mark. Nowadays, acts publication in most civilized countries is already irrelevant.

Structural requirements include providing internal content of legal certainty.

The basic requirement of legal certainty is a clear formulation of norms. "A norm cannot be regarded as a "law" unless it is formulated with sufficient precision to enable the citizen - if need be, with appropriate advice - to foresee, to a degree that is reasonable in the circumstances, the consequences which a given action may entail" 16 . This rule in Ukraine should be understood from the perspective of Article 19 of the Constitution of Ukraine: "no one can be forced to do something that is not required by law".

Statutory provision could be void if it is too "vague"17. This rephrasing of a clear formulation set the requirement that the norm must be "clear enough". The level of required clearness depends on the limitations that it sets. Law could not be clear

12 Barak, A. Purposive Interpretation in Law. Princeton: Princeton University Press, 2006, p. 51.

13 Sunday Times $v$. The United Kingdom, No. 6538/74, \$49, 2 EHRR 245.

14 Ukaz Prezydenta Ukrainy «Pro porjadok oficijnogo opryljudnennja normatyvno-pravovyh aktiv ta nabrannja nymy chynnosti» [On the Official Publication of Regulations and Their Entry into Force]. Oficijnyj visnyk Ukrainy. 1997, 24.

15 Ukaz Prezydenta Ukrainy «Pro opublikuvannja aktiv zakonodavstva Ukrainy v informacijnomu bjuleteni «Oficijnyj visnyk Ukrainy» [On Publication of Legislative Acts of Ukraine in the Newsletter "Official Gazette of Ukraine”]. Urjadovyj kurjer, 1996.

16 Olsson v. Sweden (No. 1), No. 10465/83, \$61, A 130.

17 Nowak, J.; Rotunda, R. Constitutional Law. 8th edition. Eagan MN: West, 2010, p. 1280. 
for all people on the same extent. Intellectual development, legal awareness and other factors play a great role for the "general clearness of the law". Law is not only one or two statutes. Law is a complex social phenomenon, so it must be interpreted in complex. So, concrete regulation could be "clear enough" if it has concrete mechanism of legal behavior after its complex interpretation. Such understanding of "clearness provision" is tempting to conclude that the law is not clear only in the case, when a professional lawyer after its interpretation using all possible sources could not understand regulation mechanism and legal meaning of such law.

Justice of law must be mentioned in this context. Rawls noted that injustice of a general law may be sufficient grounds for failure to be ${ }^{18}$. If law is obviously unfair, it cannot be performed as law even in case it will match the formal attributes of the law. This case is extreme and rarely applicable. Rawls also noted that unjust laws are recognized if they do not overstep certain limits of injustice ${ }^{19}$, to sum up, Rawls position, the clear wording of law, clarity of content and mechanism of effectiveness nullifying its theoretical injustice.

Generality of the law that implies restrictions is also one of the legal certainty's structural components. Law must be general and could be applied for all. Substance but not the wording of the act must be general ${ }^{20}$. "General" law in wording could be selective in substance. Such limitation could not be recognized as "general" for the constitutional rule of equality. Moreover, law could not be general if the group at which limitations are aimed is easily-recognized. The legislator must check the generality of the limitation laws in case because real reasons of the laws and target group in some cases are hardly identified. Generality of the law is one of the variations of the equality before the law. If the law is not general, people are not equal before the law. Some of them have unjustified privileges, but other are discriminated. It must be notified that not all "non-general" laws are unjust and discriminatory. There is a case when the law is aimed at the vulnerable group's special protection. Only such privilege could be the legitimate aim of the non-generality of law. In all other cases, generality of the law is required.

Another structural component of legal certainty is predictable policy ${ }^{21}$, which covers lack of making unexpected changes to legislation. Legislators should avoid

18 Rawls, J. A Theory of Justice. Cambridge, Massachusetts: Belknap Press of Harvard University Press, 1999, p. 482.

19 Ibid., p. 483.

20 Barak, A. Proportionality. Constitutional Rights and Their Limitation. Cambridge: Cambridge University Press, 2012, p. 115.

21 Ushakova, L.V.Pryncyp pravovoj opredelennostykak əlement normatyvno-pravovoj konstrukcyy socyalnogo gosudarstva [The Principle of Legal Certainty as a Part of the Legal Structure of the Welfare State]. [interactive]. [accessed on 14-11-2013]. <http://problemanalysis.ru/Dokladi2/ Ushakova.pdf $>$. 
creating conflicts that can disorient a subject in legislation and ensure the stability of law, which should be understood as the absence of frequent changes in regulations ${ }^{22}$.

The predictability of legislative policy and the stability of law are ensured by the general laws, but not highly specialized rules. General laws always are more predictable than concrete and sudden orders. A concrete rule may be partially changed when the general rule in this case remains unchanged. In the first place, in the presence of abstract and general rules of regulation, there is a quality of enforcement.

The predictable policy must be implemented by using the common standard of the legislative policy. The most important standard in the predictability of the legislative policy is the legitimate aim that is guided for the legislators. The legitimate aim for restricting human rights is such aim that can justify a particular limitation of rights. Objectives that may justify restricting the rights should be based on the values, on which constitutional democratic society is built ${ }^{23}$.

The legitimate aim is not always clearly defined in law. This goal cannot be expressed, but have a nature in the spirit of the law, principles of democracy and the rule of law. A striking example of purpose limitation is to protect human rights as well as the need to limit human rights in order to protect them and to satisfy the public interest.

The legitimate aim question does not apply to the most appropriate boundaries and limits of human rights. In fact, the legitimate aim is the mechanism, by which the state is determined based on when such limitations are done.

The legitimate aim derives primarily from the democratic values, which are provided in the letter or spirit of the Constitution. Purpose limitation is contrary to the constitutional principles of society, which is unlawful by default ${ }^{24}$. Therefore, the law, the only purpose of which is to restrict certain rights without positive effects for others, is the law that has no legitimate aim.

Sufficient legitimate public interest, which is the sum of general interest and ensures constitutional rights, is the most referred legitimate aim. The availability of public interest also includes presence of the state, national security, public order, tolerance, protection of personal feelings, which are not often related to constitutional rights. They are derived from the Constitution itself. The uniqueness of democratic understanding of this issue is that not any public interest may be legitimate grounds for limiting human rights.

Not all statutes or other acts contain an exhaustive and indicative list of legitimate purposes. However, it does not mean that the law in this case is absolute. Lack of written purposes is not a sign of the absence of such purposes. The absence of such

22 Shevchuk, S. V. Sudova pravotvorchist: svitovyj dosvid i perspektyvy v Ukraini [Judicial Lawmaking: International Experience and Prospects in Ukraine]. Kiev: Referat, 2007, p. 323.

23 Van der Schyff, G. Limitation of Rights: A Study of the European Convention and the South African Bill of Rights. Netherlands: Wolf Legal Publishers, 2005, p. 145.

24 Woolman, S.; Botha, H. Limitations. Constitutional Law of South Africa. 2002: 73. 
purposes can be covered by the use of preamble that sets out general objectives of regulation or even the Constitution and the democratic foundations of society.

Another important legitimate aim is the protection of universally recognized rights of others ${ }^{25}$. This rule is enshrined in some cases, but this goal is defined as acknowledged in most cases. The protection of human rights is always the question of the limits of protection as to ensure a balance necessary to restrict the rights of others. A clear demarcation of the boundaries of subjective rights is difficult for the reasons for the prevalence of such legitimate aim. A striking example of the limitations of rights to freedom of speech is to protect the right to privacy. The same principle of constant limitation and balance of the rights effectively acts in the field of business rights and property rights, etc. In fact, the state limits the rights of a group of people in order to fulfill the duty to protect another group.

However, the most obvious aim in limiting certain rights is to meet the public interes $\mathrm{t}^{26}$. The category of public interest was created because it restricts the rights of society to achieve the overall outcome (good). Availability of public interest clearly demonstrates not absolute rights and opportunity and the need for restrictions. If importance and necessity of public interest is obvious, its contents and characteristics are not so obvious.

The public interest that is achieved should be clear and used for, as noted by Dworkin, "Disaster Prevention" and "Achieve an obvious and important public good" 27. The public interest and the evidence and the importance of such restrictions must be easy-understandable to most people. It is necessary to demonstrate the required level to limit public awareness of fundamental rights and freedoms.

Ensuring national security is an obvious aim for limiting the rights. This goal is common and necessary. However, it is clear that restrictions should be discontinued as soon as a threat to national security is felt or it is no longer reduced.

The protection of public order is related to the national security ensuring the legitimate aim. In fact, when the threat to national security is reduced, there is one important issue of the protection of public order. The protection of public policy is an important element of human rights, because there is no freedom without order. The protection of public order is recognized important not only at a national level, but also enshrined in several international treaties. The main feature of public policy is that it should be interpreted according to the circumstances of the situation. It is generally accepted that the prevention of crime, protection of minorities and public health are covered by the protection of public order. In fact, the category of 
public order is the most open for interpretation, as regards any aspect of the effective functioning of society and the state.

It is a discussible question whether the democratic order in society could be a legitimate aim or not. Thus, Barak believes that such a goal is important in limiting the rights ${ }^{28}$. However, such a goal cannot be universal because not all countries recognize democracy as a fundamental principle of society. Therefore, making discussions about the nature, form and characteristics of democracy may affect the efficiency of the principle of proportionality usage.

The list of objectives that fall under the category of the "legitimate aim" is only approximate because society sets out a number of priorities for its development, and therefore, each particular restriction has a specific purpose that is directly or indirectly established in the law. A striking example of such non-standardized aims is the protection of religious values. It can be a legitimate aim at the concrete situation or even part of the public order. In the atheist society, protection of religious values does not even rise because most people do not care about this.

A clear division of powers and responsibilities between branches is a classical requirement of legal certainty. The separation of powers is a general legal requirement that is part of the rule of law. Separation of powers plays a role in preventing the intersection of competence to ensure confidence in the stability of enforcement. The division of powers based on a system of checks and balances is a legal certainty guarantee against frequent and arbitrary changes in the positive law prevention ${ }^{29}$.

The uniqueness and predictability of enforcement is probably the most important structural requirement of legal certainty. This value is the most important in case-law appliance to new social relations in the development of society. A person should always be able to orient behavior to apply the requirements of the rules at the time of action.

Courts play a key role in ensuring predictable enforcement. Other legal enforcement agencies may be appealed in court. Judicial enforcement is crucial. Ferejon notes that both national and supranational courts have begun to play a much more active and greater role in addressing important and controversial social issues that were previously resolved by the government ${ }^{30}$. Strengthening of the courts in the legal field is so large that there is a risk of power concentration by the judiciary, which can lead to the rule of law transformation from to the rule of judges ${ }^{31}$. Tamanaha thought that the legal rules must be applied by judges in the same way - the judge

28 Barak, A. Proportionality: Constitutional Rights and Their Limitations. Cambridge: Cambridge Studies in Constitutional Law, 2012, p. 268.

29 Radbruch, G. Rechtsphilosophie. Leipzig: Verlag von Quelle \& Meyer, 1932, p. 160.

30 Ferejon, J.; Pasgino, P. Rule of Democracy and the Rule of Law. Cambridge: Cambridge University Press, 2003, p. 239.

31 Kozjubra, M.I. Verhovenstvo prava: ukrainski realii ta perspektyvy [Rule of Law: The Ukrainian Realities and Prospects]. Pravo Ukrainy. 2010, 3: 6-18. 
speaks on behalf of the law, the judge is the embodiment of the law ${ }^{32}$. The importance of credibility and certainty of judgments is essential in ensuring compliance with legal certainty. According to the ECHR position in "Sovtransavto Holding against Ukraine", the uniqueness of judgments in the application and interpretation of domestic law plays an important role in ensuring the principle of legal certainty ${ }^{33}$. "When the courts finally decided to issue their decision should not be questioned" 34 .

Hurvich $^{35}$ noted that the stability of the judgment must be provided by the following requirements:

- Inability to review the decision, which entered into force;

- Inability of a new trial that could lead to the cancellation or modification of previously rendered decisions;

- Compulsory execution of judgments.

Abolishment of final decisions review and submission creates the real reason for the implementation of the law and reasonable expectations. The stability of the legal decision is not only a requirement of the principle of certainty, but also a guarantee of procedural norms, which corresponds to the principle of legal certainty.

\section{Legal certainty in the ECHR practice}

Legal certainty takes its beginning in the days of classical Athenian democracy and the Roman Empire, but the greatest impetus for its development was made by the ECHR on the interpretation of the European Convention on Human Rights and Fundamental Freedoms (hereinafter - the Convention).

One of the first cases, in which the ECHR used the legal certainty principle, is Sunday Times $v$. The United Kingdom case ${ }^{36}$. The Court notes that the term "prescribed by law" in the Convention implies observance of legal certainty. The Court argues that the term "prescribed by law" includes not only written law, such as the statutes, but unwritten that is enclosed in the society rules and principles of morality.

In Steel and Others $v$. The United Kingdom case ${ }^{37}$, the ECHR emphasized that the Convention requires either the written or unwritten law, which was sufficiently precise to allow the citizen, if needed, with appropriate advice to predict some extent in certain circumstances and the consequences which an action may entail. Phrases

Tamanaha, B. On the Rule of Law: History, Politics, Theory. Cambridge: Cambridge University Press, 2004, p. 205.

33 Sovtransavto Holding v. Ukraine, No. 48553/99, \$79, ECHR 621.

34 Brumărescu v. Romania, No. 28342/95, \$61, 62, ECHR 1999-IV.

35 Gurvych, M. A. Sudebnoe reshenye. Teoretycheskye problembl [The Court Decision. Theoretical Issues]. Moscow: Jurydycheskaja lyteratura, 1976, p. 46.

36 Sunday Times $v$. The United Kingdom, No. 6538/74, \$49, 2 EHRR 245.

37 Steel and Others $v$. The United Kingdom, No. 24838/94, \$54, 1998-VII, No. 91. 
"lawful" and "in accordance with the procedure established by law" make full respect for fundamental procedural rules of national law.

In Kruslin v. France case $\mathrm{e}^{38}$, the ECHR concluded that the restriction of human rights under the Convention may be done only if they are necessary in a democratic society. The phrase "under the law" provides a certain quality of the law requiring it to be accessible to a person, and it could foresee the consequences of its use and that the law is not contrary to the rule of law. Formulation of laws should be sufficiently clear and understandable to give citizens the necessary information concerning the circumstances and conditions under which public authorities may interfere to their individual rights.

In Novik v. Ukraine case ${ }^{39}$, the ECHR stated that deprivation of liberty is an extremely important sphere of legal certainty usage. The requirement of "quality of law" provides that the law must be sufficiently accessible, precise and foreseeable in its application in order to avoid any risk of arbitrariness.

Baranowski v. Poland case ${ }^{40}$ determined that the principle of legal certainty provides precise formulation of the conditions under which the restriction or deprivation of liberty could be made. The ECHR held that the Polish criminal law at that time did not have clear provisions regarding extension of detention in custody at the trial stage if a person detained under investigation. The ECHR noted that practice of delaying person for an indefinite period of time was unforeseeable. So, this custody was not provided by law because it was totally unforeseeable.

In Hashman and Harrup v. The United Kingdom case ${ }^{41}$, the ECHR pointed out that one of the requirements flowing from the expression "prescribed by law" is foreseeability. Norm cannot be regarded as "law" unless it is formulated with sufficient precision that gives the person an opportunity to be guided by this rule in their actions. If the law is extremely desirable to ensure it can lead to overregulation, while the law should never keep up with changing circumstances. The degree of clarity should ensure formulation of national laws and cannot cover all eventualities. It largely depends on the content of this document, the scope covered by this law, as well as the number and status of those to whom it is addressed.

In Olsson v. Sweden case ${ }^{42}$, the ECHR defined that the law, which granted certain powers to public authorities, shall be written with sufficient clarity and accounted for a legitimate purpose to give the individual adequate protection against arbitrary interference.

38 Kruslin v France, No. 11801/85, \$30, 12 EHRR 547.

39 Novik v. Ukraine, No. 48068/06.

40 Baranowski v. Poland, No. 28358/95, 2000-III.

41 Hashman and Harrup v. The United Kingdom, \$31, 30 EHRR 241.

42 Olsson v. Sweden (No. 1), No.10465/83, \$61, A 130. 
In Rekvényi v. Hungary case ${ }^{43}$, the ECHR carefully considers the predictability criterion of behavior in the future. Norm cannot be considered as "law" unless it is formulated with sufficient precision, which entitles to follow this rule in their actions. A person must be able, if needed, with appropriate advice to foresee sufficient consequences, which may result in his action. Predictability of consequences with absolute certainty is not required because it cannot be achieved. Many laws inevitably draw more or less vague terms, interpretation and application of which are questions of practice. The role of the trial is precisely to dissipate such interpretational doubts. The degree of clarity that is provided in the formulation of national laws depends on the content of this document, areas, to which it applies, and the number and status of those, to whom the law is addressed, e.g., the degree of clarity in the Constitution that the given general nature of rights may be lower than in other laws.

In Ryabykh $v$. Russia case ${ }^{44}$, the ECHR points out that the principle of legal certainty inter alia provides that in cases, where the court makes the final decision, such decision cannot be challenged. The principle of legal certainty includes the final judgment. This principle provides that the parties may seek a review of a judgment, which is final and enforceable only in order to view and make a new judgment to correct judicial errors not connected with matter of the decision changing. Deviations from this principle are justified only in the presence of significant and indisputable circumstances.

The Court clearly indicates that the theoretical principle of legal certainty has practical applications in various fields. Thus, different requirements of legal certainty influence legislative and judicial power. Moreover, legal certainty plays an important role in ensuring sustainable management and dynamic development of the law.

\section{Practical application of legal certainty in land relationships in Ukraine}

Legal certainty has a special role in spheres, which are on the public and private fields' intersection. Land law relates to public law in one situation and to private in other. Land law has an imperative-dispositive regulation manner. So, its specificity often refers to legal certainty for settling public-private disputes.

The most practical justification of legal certainty in Ukraine was done by the Constitutional Court of Ukraine. Particular attention should be drawn to the application of legal certainty by the Constitutional Court of Ukraine on the rules governing land legislation, as well as opinions in other spheres that can be applicable to the provisions of land law in Ukraine. 
The Constitutional Court of Ukraine in Section 3.1 of the Decision on 29.06.2010 № 17-рп/2010 ${ }^{45}$ has given its own definition of legal certainty and noted that its main criterion is predictable consequences and clarity wording: "One of the elements of the rule of law is the principle of legal certainty which states that the restriction of basic human rights and implement these restrictions in practice allowed only in the case of ensuring predictable application of legal rules imposed by such restrictions. That limitation should be based on the criteria that will allow a person to separate legal from illegal behavior, provide the legal consequences of his conduct".

According to Articles 13 and 14 of the Constitution of Ukraine, land is the property of the Ukrainian nation, the main national wealth that is under the state guardianship and property rights are carried by public bodies within the limits set by the Constitution. The Constitution of Ukraine does not specify the legal regulation of land areas, except for the underscore guarantee of land ownership. Stability of the Constitution gives a clear picture of the importance of the land at the same time without detailing specific rules, which can be permanently changed.

In accordance with Section 4 of the Conclusion of the Constitutional Court of Ukraine of 02.06.1999 № 2-B/9946, "one of the most important conditions of certainty in the relationship between citizen and state guarantees and mechanism of realization of a principle of the inviolability of human rights and freedoms is the stability of the Constitution which is determined by the legal content of the Basic Law. Availability in the Constitution of Ukraine too detailed provisions that must be placed in the current legislation will cause to nourish the frequent amendments to the Constitution. It can be negatively marked on the stability of the Basic Law". Establishment of only general rules in land regulations in the Constitution of Ukraine plays an important role in the context of the land relations stability, but not prevent rapid response to social relations changes in the land sphere. The Constitutional Court of Ukraine identified that the law must be stable, but its interpretation changing in the context of current conditions recalling the ECHR case-law Tyrer $v$. The $U K^{47}$. One of the aims of legal certainty in the land sphere is to ensure the stability of the text as the Constitution and laws.

The Constitutional Court of Ukraine in Paragraph 10 Section 2.1 of the Decision on 26.12.2011 № 20-рп/2011 $1^{48}$ indicated that the mechanism of rights realization may be amended by the state in the context of current conditions, e.g., "...because of the impossibility of financing by proportional redistribution to maintain the balance of the

45 The Constitutional Court of Ukraine, 29 June 2010, Decision №17-pп/2010. Visnyk Konstytucijnogo Sudu Ukrainy. 2010, № 5.

46 The Constitutional Court of Ukraine, 2 June 1999, Conclusion №2-в/99. Visnyk Konstytucijnogo Sudu Ukrainy. 1999, № 3.

47 Tyrer $v$. The United Kingdom, No. 5856/72, \$30, [1978] ECHR 2.

48 The Constitutional Court of Ukraine, 26 December 2011, Decision №20-pп/2011. Oficijnyj visnyk Ukrainy. 2012, № 3. 
public and private interests". Implementation of legal certainty in land law requires that the text of the Constitution must be stable and the mechanism of ambush rules changes only for the society interests' balance.

In Section 4.1 of the Decision of the Constitutional Court of Ukraine on 01.04.2008 № 4-рп/2008 ${ }^{49}$ special attention was drawn to the need for a clear separation of powers: "The division of state power is a structural differentiation of the three equivalent basic state functions: legislative, executive and judicial. It reflects the functional certainty of each government body. It provides not only separation of powers but also their interaction. System of mutual checks and balances is aimed at ensuring their cooperation as a single state". Functional separation of powers affects different areas of public life, including land sphere. Separation of powers is important in the context of preventing duplication of competence and ensuring implementation of legal certainty in the land sphere.

If the separation of powers is enforced and implemented in functional certainty, applicability of binding acts adopted by such authorities plays an important role. "Land legislation" term is explained in Section 1 Article 4 of the Land Code of Ukraine ${ }^{50}$ : "Land legislation includes this Code and other normative legal acts in the sphere of land relations". Moreover, the Constitutional Court of Ukraine interpreted a similar provision of the Labor Code of Ukraine in Decision on 09.07.1998 № 12-pп/9851. The Constitutional Court of Ukraine found that the term "legislation" includes regulations adopted by the authorities under the law and within the authority. To sum up, if the law includes all legislation in a concrete sphere, such legislation also must satisfy legal certainty requirements in all spheres of regulation.

The key decision of the Constitutional Court of Ukraine in the legal certainty usage in land relations is Decision on 22.09.2005 № 5-pп/2005 52. The Constitutional Court of Ukraine ruled unconstitutional the law, which established the obligation to reissue of land permanent use (form of property, when all land in de iure state property but person or legal entity can be an owner de facto with a limitation of disposal) for the property or lease without legal, organizational and financial support, as well as loss of land of permanent use, previously granted after term for such reissue.

The reason for unconstitutionality of such norms was disparity of the legal certainty requirements. In Paragraph 3 Section 5.4 of this Decision, the Constitutional

49 The Constitutional Court of Ukraine, 1 April 2008, Decision №4-pп/2008. Visnyk Konstytucijnogo Sudu Ukrainy. 2008, № 2.

50 Земельний кодекс України [Land Code of Ukraine]. Vidomosti Verhovnoi Rady Ukrainy. 2002, 3-4.

51 Constitutional Court of Ukraine, 9 July 1998, Decision №12-pп/98. Oficijnyj visnyk Ukrainy. 1998, № 32.

52 Constitutional Court of Ukraine, 22 September 2005, Decision №5-pп/2005. Oficijnyj visnyk Ukrainy. 2005, № 39. 
Court of Ukraine set that "requirements for reissuing rights to use the land does not meet the requirement of clarity and legal certainty standards: these provisions suggest spreading this concept only in cases of initial receipt of land from state and municipal owned enterprises, institutions and organizations belonging to the state or municipal property as well as citizens and legal entities which acquire ownership and use of land". In Paragraph 5 Section 5.4, the Court noted that the rate of reissuing of land title does not comply with legal certainty because of the absence of corresponding renewal process. Therefore, there are no clarity results of their actions. The need for predictability of legislative policy was appointed in the way that "... present conditions shall not be degraded by the new law or other legal act adoption". The main idea in that Decision was that in the case of complete uncertainty of the law, there is no law: "when permanent use transfers to the long-term lease "in accordance with the law" term this is incorrect due to the uncertainty of this law as a law that would set the reissuing procedure".

To sum up, legal certainty begins to penetrate into the Ukrainian legal system. Nowadays, this process is very slow and developed only by the scholars and the Constitutional Court of Ukraine. From the other hand, uprising of the rule of law and other fundamental principles of law application is moving in a positive way. This positive tendency could be found not only in constitutional law, but also in different branches of law, such as land law.

\section{Conclusion}

The above-mentioned theoretical and practical background may be summed up in a following way: the principle of legal certainty is a fundamental principle, which must comply with legislation and enforcement. Legal certainty principle takes its origins from Ancient Greece and Rome, as it was mentioned in the first part of the article. Greeks used legal certainty as a main criterion for just legislation, but Romans understood it as a requirement for judicial activities. Modern requirements of the legal certainty principle have the same spheres of usage - legislative and judiciary. The main of them are the following: restrictions must be provided for a specific legal act, which is public, predictable and general, clearly formulated, has legitimate public interest; clear division of powers and responsibilities; enforcement must be unique and predictable. All these requirements could be found in the ECHR practice. The principle of legal certainty plays an important role in the legal regulation of land relations through the public law method.

At the same time, introduction of the legal certainty principle requirements in Ukraine firstly must be deeply cultivated in the sphere of law executions, especially by the judiciary. 


\section{References}

Alexy, R. A Theory of Constitutional Rights. Oxford: Oxford University Press, 2002.

Barak, A. Proportionality: Constitutional Rights and Their Limitations. Cambridge: Cambridge Studies in Constitutional Law, 2012.

Barak, A. Purposive Interpretation in Law. Princeton: Princeton University Press, 2006.

Baranowski v. Poland, No. 28358/95, 2000-III.

Brumărescu v. Romania, No. 28342/95, ECHR 1999-IV.

Bruno, L. Freedom and the Law. Los Angeles: Nash Publishing, 2008.

Dozhdev, D. V. Rymskoe chastnoe pravo [Roman Private Law]. Moscow, 2008.

Dworkin, R. Rights as Trumps. Theories of Rights. New York: Oxford University Press, 1984.

Ferejon, J.; Pasgino, P. Rule of Democracy and the Rule of Law. Cambridge: Cambridge University Press, 2003.

Gurvych, M. A. Sudebnoe reshenye. Teoretycheskye problemy [The Court Decision. Theoretical Issues]. Moscow: Jurydycheskaja lyteratura, 1976.

Hayek, F. Law, Legislation and Liberty. Vol. 2. London and Chicago: University of Chicago Press, 1976.

Hashman and Harrup v. The United Kingdom, EHRR 241.

Held, V. The Public Interest and Individual Interests. New York: Basic Books, 1970.

Kozjubra, M. I. Verhovenstvo prava: ukrainski realii ta perspektyvy [Rule of Law: The Ukrainian Realities and Prospects]. Pravo Ukrainy. 2010, 3: 6-18.
Konstytucija Ukrainy [Constitution of Ukraine]. Vidomosti Verhovnoi Rady Ukrainy. 1996, № 30.

Kozjubra M. I. Pryncyp verhovenstva prava ta pravovoi derzhavy: jednist osnovnyh vymog [Rule of Law and Rechtsstaat: The Unity of the Basic Requirements]. Naukovi zapysky NaUKMA. 2007, 64 (Jurydychni nauky): 3-9.

Kruslin v France, No. 11801/85, 12 EHRR 547.

Matvejeva, Ju.I. Pryncyp pravovoi vyznachenosti: istorychni pidhody ta suchasne rozuminnja [The Principle of Legal Certainty: Historical Approaches and Current Understanding]. Naukovi zapysky NaUKMA. 2011, 116 (Jurydychni nauky): 29-31. Nowak, J.; Rotunda, R. Constitutional Law. 8th edition. Eagan MN: West, 2010.

Novik v. Ukraine, No. 48068/06; Sunday Times $v$. The United Kingdom, No. 6538/74, 2 EHRR 245.

Olsson v. Sweden (No.1), No. 10465/83, A 130.

Pokrovskyj, Y. A. Osnovnye problemy grazhdanskogo prava [The Main Problems of Civil Law]. Moscow, 1998.

Radbruch, G. Rechtsphilosophie. Leipzig: Verlag von Quelle Meyer, 1932.

Rawls, J. A Theory of Justice. Cambridge, Massachusetts: Belknap Press of Harvard University Press, 1999.

Rehtyna, Y.V. Pravovaja opredelennost (res judicata) $\mathrm{v}$ ystoryy prava Drevnego Ryma. [Legal Certainty (Res Judicata) in Legal History of Ancient Rome]. Ystoryja gosudarstva y prava. 2011, 22: 43-47. 
Sovtransavto Holding v. Ukraine, No. 48553/99, ECHR 621.

Steel and Others $v$. The United Kingdom, No. 24838/94, 1998-VII, No. 91.

Sunday Times $v$. The United Kingdom, No. 6538/74, 2 EHRR 245.

Shevchuk, S. V. Sudova pravotvorchist: svitovyj dosvid i perspektyvy $v$ Ukraini [Judicial Lawmaking: International Experience and Prospects in Ukraine]. Kiev: Referat, 2007.

Tamanaha, B. On the Rule of Law: History, Politics, Theory. Cambridge: Cambridge University Press, 2004.

The Digest of Justinian. Vol. 2. Philadelphia: University of Philadelphia Press, p. 27-28.

Tyrer $v$. The United Kingdom, No. 5856/72, [1978] ECHR 2.

The Constitutional Court of Ukraine, 9 July 1998, Decision №12-pп/98. Oficijnyj visnyk Ukrainy. 1998, № 32.

The Constitutional Court of Ukraine,

2 June 1999, Conclusion №2-в/99.

Visnyk Konstytucijnogo Sudu Ukrainy. 1999, № 3.

The Constitutional Court of Ukraine, 22 September 2005, Decision №5рп/2005. Oficijnyj visnyk Ukrainy. 2005, № 39.

The Constitutional Court of Ukraine, 1 April 2008, Decision №4-pп/2008. Visnyk Konstytucijnogo Sudu Ukrainy. 2008, № 2.

The Constitutional Court of Ukraine, 29

June 2010, Decision №17-рп/2010. Visnyk Konstytucijnogo Sudu Ukrainy. 2010, № 5.
The Constitutional Court of Ukraine, 26 December 2011, Decision №20рп/2011. Oficijnyj visnyk Ukrainy. 2012, № 3.

Ukaz Prezydenta Ukrainy «Pro porjadok oficijnogo opryljudnennja normatyvno-pravovyh aktiv ta nabrannja nymy chynnosti» [On the Official Publication of Regulations and Their Entry into Force]. Oficijnyj visnyk Ukrainy. 1997, № 24.

Ukaz Prezydenta Ukrainy «Pro opublikuvannja aktiv zakonodavstva Ukrai'ny v informacijnomu bjuleteni «Oficijnyj visnyk Ukrainy» [On Publication of Legislative Acts of Ukraine in the Newsletter "Official Gazette of Ukraine”]. Urjadovyj kurjer. 1996.

Ushakova, L. V. Pryncyp pravovoj opredelennosty kak element normatyvnopravovoj konstrukcyy socyalnogo gosudarstva [The Principle of Legal Certainty as a Part of the Legal Structure of the Welfare State]. [interactive]. [accessed on 14-112013]. <http://problemanalysis.ru/ Dokladi2/Ushakova.pdf $>$.

Van der Schyff, G. Limitation of Rights: A Study of the European Convention and the South African Bill of Rights. Netherlands: Wolf Legal Publishers, 2005.

Woolman, S.; Botha, H. Limitations. Constitutional Law of South Africa. 2002, 73.

Zemelnyj kodeks Ukrainy [Land Code of Ukraine]. Vidomosti Verhovnoi Rady Ukrainy. 2002, 3-4. 


\title{
TEISINIS TIKRUMAS KAIP PAGRINDINIS UKRAINOS ŽEMĖS TEISĖS PRINCIPAS
}

\author{
Bronislav Totskyi \\ Ukrainos nacionalinès mokslų akademijos \\ Koretskio valstybès ir teisès institutas, Ukraina
}

\begin{abstract}
Anotacija. Teisinio tikrumo principas yra bendrasis teisès principas, kildinamas iš antikinès Graikijos ir Romos. Šiandien šis principas yra pripažistamas demokratine vertybe, kuri laikoma Europos bendrojo paveldo dalimi. Ukraina šiuo metu derina nacionalinius teisés aktus su europiniais standartais, o teisinio tikrumo kriterijaus ivedimas i nacionalinę teisés sistema yra sudetingas procesas. Vis dèlto Ukraina jau yra žengusi dideli žingsni ịtvirtinant teisinio tikrumo principq žemès teisès srityje. Ukrainos istatymy leidejas ir teismai pozityviai veikia teisinio tikrumo principo praktini taikyma. Ypač svarbi funkcija šiame procese skiriama Ukrainos Konstituciniam Teismui, kuris pastaruoju metu dažnai taiko analizuojama principą.
\end{abstract}

Reikšminiai žodžiai: teisinis tikrumas, numatomumas, nuspëjamumas, vykdymas, EŽTK, žemès teisè.

\section{LEGAL CERTAINTY AS A BASIC PRINCIPLE OF THE AND LAW OF UKRAINE}

\author{
Bronislav Totskyi \\ National Academy of Sciences, \\ Koretsky Institute of State and Law, Ukraine
}

Summary. The principle of legal certainty is a general principle of law. It takes its origin from Ancient Greece and Rome. Greeks used legal certainty as a main criterion for just legislation, but Romans understood it as a requirement for judicial activities. Modern requirements of the legal certainty principle have the same spheres of usagelegislative and judiciary. The main of them are the following: restrictions must be provided for a specific legal act, which is public, predictable and general, clearly formulated, has legitimate public interest; clear division of powers and responsibilities; enforcement must be unique and predictable. Nowadays, legal certainty is a generally recognized democratic value that is part of the European common heritage. The European Court of Human Rights has a great influence on the legal certainty formation. It has stable practice of using the legal certainty principle in different spheres. The ECHR has developed legal certainty to the level that it has now. 
Legal certainty begins to penetrate into the Ukrainian legal system. Nowadays, this process is very slow and developed only by the scholars and the Constitutional Court of Ukraine. From the other hand, uprising of the rule of law and other fundamental principles of law application is moving in a positive way. This positive tendency could be found not only in constitutional law, but also in different branches of law, such as land law. The Constitutional Court of Ukraine tries to use the concept of "living instrument" that was established by the ECHR in Tyrer v. The United Kingdom case. The majority of legal certainty requirements in land sphere are connected to the legislative usage. Predictability of the acts and legislative policy is the most problematic aspect of the legal certainty implementation in Ukraine.

Keywords: legal certainty, foreseeability, predictability, enforcement, ECHR, land law.

Bronislav Totskyi, Ukrainos nacionalinès mokslų akademijos Koretskio valstybės ir teisès instituto doktorantas. Mokslinių tyrimų kryptys: teisinè valstybė, žemès teisè, proporcingumo principas.

Bronislav Totskyi, National Academy of Sciences of Ukraine, Koretsky Institute of State and Law, PhD student. Research interests: rule of law, land law, principle of proportionality. 